2 Hope PL, Hall MA, Millward-Sadler GH, Normand, ICS. Alpha-1-antitrypsin deficiency presenting as a bleeding diathesis in the newborn. Arch Dis Child 1982;57:68-70.

${ }^{3}$ Fidalgo I, Vazquez C, Rodriguez-Soriano J. Intracranial haemorrhage due to vitamin $\mathrm{K}$ deficiency associated with alpha1-antitrypsin deficiency type $\mathrm{P}_{\mathrm{i}} \mathrm{Z}$. (letter). Arch Dis Child 1982;57:722.

4 Jenkins HR, Leonard JV, Kay JDS. Alpha-l-antitrypsin deficiency, bleeding diathesis, and intracranial haemorrhage. (letter). Arch Dis Child 1982;57:722-3.

K D Foote AND M BuRch General Infirmary of Leeds, Leeds LS2 9NS

\section{.... And children first?}

Sir,

I can assure Professor Smithells ${ }^{1}$ that most women in Liverpool (and presumably in Leeds also) go to work not because of what they have read from female journalists but to keep themselves or their family out of poverty. It is not uncommon for the woman to be the only breadwinner in a family.

It is disappointing that while Professor Smithells is happy to criticise teachers and journalists his criticism of paediatricians is less forthright. The truth is that the BPA and its journal Archives of Disease in Childhood have remained silent on the major social issues that affect the health of children for too long. To give but a few examples:

(1) Smoking. Why is it only the BMA that is issuing press statements on tobacco advertising when it is in childhood (primary and secondary school) that smoking is started. Paediatricians should be at the forefront of the medical profession's campaign against smoking.

(2) Car safety. The excellent article by Sprigg $^{2}$ would have benefited from a short editorial endorsing the suggested recommendations and an accompanying press release. If it is not BPA policy to try and save children's lives by legislation then it should be.

(3) Breast feeding. This is emphasised by David Morley as a priority in the Third World $;^{3}$ is it not also a priority in the United Kingdom? The silence of British paediatricians with regard to the WHO code of marketing of breast milk substitutes is scandalous.

(4) Poverty. With nearly one in three children living in poverty ${ }^{4}$ this is a major issue that directly affects child health-both physically and mentally. Should we not put pressure on the government to increase child and supplementary benefits?

(5) Unemployment. It is now accepted by a majority of schoolchildren in inner city areas that they will not get a job when they leave school. What is the psychological effect of the threat of unemployment on these children? Again the discussion on unemployment and health within the medical profession has been ignored by paediatricians.

The medical profession is one of the most powerful pressure groups within the country. There is no doubt in my mind that paediatricians if seen to be campaigning for the rights of children could be very effective-both in terms of changes in legislation and also by utilising the mass media to get our message across to children. The question that remains is what will it take to get paediatricians into action?

\section{References}

1 Smithells RW. . . A And children first? Arch Dis Child 1985;60:781-2.

2 Sprigg SJ. Passenger safety in cars. Arch Dis Child 1985;60: 678-9.

3 Morley D. 'The state of the world's children'. Arch Dis Child 1985;60:693-4.

${ }^{4}$ Mack J, Lansley S. Poor Britain. Australia: George Allen \& Unwin, 1985.

I A ChOonara University of Liverpool, Liverpool $L 693 B X$

Professor Smithells comments:

Sir,

I would not take issue with anything Dr Choonara writes. I appreciate that mothers may have to go out to work for economic reasons, although my comment specifically excluded single parent families. The breast feeding/milk advertising issue is of principal importance in the Third World, whereas I was writing about English children. The other four specific issues mentioned by Dr Choonara are not primarily medical. Nevertheless, I asked 'Are paediatricians doing all they can ...?', the implication being that I think not; and publication in Archives makes clear to whom my comments were primarily directed.

Sir,

Dick Smithells' provocative opening remark in his 'Point of View' paper ${ }^{1}$ evokes a response in one who some years ago gave up the somewhat unequal struggle of supporting children against some aspects of British society today. He says 'Why do the English dislike children?' Why stop at the English: the inclusive term British might have been more appropriately used.

Professor Smithells only partially answers his own question, which reminded me of a comment made by a contemporary of mine many years ago in reply to a similar question. My colleague said 'The British don't actually dislike children, they just like dogs more.' Near as we are to the 21st century many British parents (some of whom are politicians and leaders of one sort or another) still cling to the tenets of the 19th century in rearing their children: 'don't spoil the brats, bring them up tough, build their character'. In short the 'stiff upper lip' syndrome is alive and well.

It has always seemed to me not without significance that our country has the Royal Society for the Prevention of Cruelty to Animals, the Royal Society for the Protection of Birds, and the National Society for the Prevention of Cruelty to Children.

Children have no votes and some politicians are content to leave them in a subsidiary, if not second class, position: 